\title{
CONTENT-PROCESS ASPECTS OF PROFESSIONAL SELF-CREATION OF FUTURE EDUCATION MANAGER
}

\author{
Tetiana Dovha ${ }^{1}$, Yaroslav Haleta ${ }^{2}$, Olena Habelko ${ }^{3}$ \\ ${ }^{I}$ Doctor of Pedagogical Sciences, Associate Professor, Central Ukrainian State Pedagogical University named \\ afterV.Vynnychenko, Kropyvnytskyi, Ukraine, e-mail: t_dovga@ukr.net, ORCID: https://orcid.org/0000- \\ 0002-4219-0194 \\ ${ }^{2}$ Doctor of Pedagogical Sciences, Associate Professor, Central Ukrainian State Pedagogical University named \\ after V.VVynnychenko, Kropyvnytskyi, Ukraine, e-mail: yaroslavhaleta@ukr.net, ORCID: \\ https://orcid.org/0000-0003-0484-529X \\ ${ }^{3}$ Candidate of Pedagogical Sciences, Associate Professor, Volodymyr Vynnychenko Central Ukrainian State \\ Pedagogical University, Kropyvnytskyi, Ukraine, e-mail: lena_gabelko@i.ua, ORCID: https://orcid.org/0000- \\ 0003-3769-3616
}

Annotation. The article is devoted to the problem of professional creation of a future education manager. The content of the concept "education management" is disclosed. The specifics of the specialty "education manager" are shown and the need for training management personnel for all links of the education system in the country is substantiated. The author's approach to the content of professional training of future managers is presented, in particular, the necessity of solving the problem of professional self-creation as a promising direction for improving the quality of professional training of qualified specialists for the field of education management is substantiated. The content-procedural aspects of the professional self-creation of future education managers have been analyzed and interpreted. For this purpose, such personal self-processes as: self-organization, self-regulation, self-presentation, self-image, self-management, self-marketing are considered. They ensure the effectiveness of professional creation of a specialist in the sphere of management. Under the influence of these self-processes, favorable conditions are created for the personal and professional development of a future manager in the field of education, prerequisites for career growth and profitable promotion of a specialist in the labor market in conditions of educational competition arise.

Keywords: education system, education management, future education manager, content of professional training, self-processes, personal development, professional self-creation.

JEL Classification: JEL I0; I20

Formulas: 1; fig.: 0; tabl.: 0; bibl.: 15

Introduction. The changes taking place in the economic, political and cultural life have put the Ukrainian society in front of the need to renew the education system. Modern educational reforms presuppose significant changes in all levels of education, and, above all, they concern the training of qualified specialists.

The sphere of education today is in need of specialists who are able to change themselves under the influence of the changes taking place in society. Only a selfsufficient, successful person will be able to adapt to the difficult conditions caused by the crisis in the life of society and realize himself in professional activities related to the provision of a wide range of educational services. The desire for self-development and self-improvement should become an integral feature of a modern specialist. In this regard, the training of a future education manager in higher education institutions should be aimed at forming the personality of a professional who owns the technologies and techniques of effective self-creation.

Literature review. The works of N. Bunyak, M. Grineva, A. Guba, L. Danilenko, V. Zhigir, L. Karamushka, N. Kolominskiy, V. Kryzhko, V. Maslov, N. Lukashevich 
E. Pavlyutenkov, M. Potashnik, V. Simonov, I. Tomashevskaya, V. Sharkunova, E. Shtepa and others. The issues of training future education managers were considered in their works by V. Berek, L. Karamushka, L. Kravchenko, V. Kryzhko, V. Oliynik. E. Pavlyutenkov, V. Pikelnaya, V. Prikhodko, E. Khrykov, V. Yastrubov and others. The results of scientific research in the field of self-processes show that many modern authors (N. Bilyk, M. Borishevsky, A. Markova, A. Mudrik, V. Mukhina, A. Novskaya, A. Ostapchuk, L. Serdyuk, T. Tsymbal, etc. .) are interested in both the process of self-creation and related processes (self-construction, self-design, selfchange). Other self-processes are constantly in the field of view of scientists: selforganization (N. Afanasyeva, L. Bobrova, A. Derkach, N. Dudnik, M. Dyachenko, A. Ishkov, L. Kandybovich, E. Klimov, M. Lukashevich, L. Fadeeva, V. Filonenko and others); self-regulation (K. Abulkhanova-Slavskaya, A. Bandura, A. Brushlinsky, M. Grineva, V. Ivannikov, O. Konopkin, B. Lomov, V. Morosanova, G. Prygin, S. Rubinstein, etc.); self-presentation (E. Goffman, W. James, I. Jones, C. Cooley, D. Myers, G. Mead, T. Pittman, M. Snyder, R. Chaldini); self-manager (N. Bunyak. V. Ischenko, N. Lukashevich, S. Simodeiko, I. Tomashevskaya, T. Tsymbal, G. Chaika, E. Shtepa, etc.).

Aim. The article assumes the analysis of the content-procedural aspects of the professional self-creation of the future education manager as a prerequisite for improving the quality of his professional training in the context of higher pedagogical education.

Methods. The main method used in article is semantic analysis of themain to understand the subject area.

Results. In the psychological and pedagogical literature, there are the following variants of the definition of the concept "education management".

Management in education is a conscious interaction of a leader with other people (subordinates, partners, leaders, students, parents) aimed at ensuring their active, coordinated participation to achieve the set goal [10].

Educational management is defined as the theory and practice of managing educational systems in order to ensure the end result (formation, self-development of the individual) based on the development of scientific and pedagogical potential, high quality of the educational process on the way of transforming the system from traditional management to self-organization [6].

An education manager is a profession, a type of activity, the basis of which is knowledge and abilities, with the help of which it is possible to manage and guide educational processes [8, p. 32].

The future education manager must know the basics of pedagogical management (planning and organizing training, developing educational and methodological support, assessing the quality of the educational process, etc.) and self-management (planning one's own activities, rational use of time, mastering the techniques of mental labor, etc.). In order to profitably present himself as a person and a professional, in the conditions of educational competition, he must constantly strive for self-improvement and self-creation. 
Self-creation. The theoretical foundations of the process of a person's selfcreation are the philosophical category of "I-concept" and the phenomenon of "self". The core of the "self" is the "I-concept" - a relatively stable, more or less conscious, experienced as a unique system of ideas of the individual about himself.

The components of the phenomenon of selfhood are numerous processes, which are denoted by complex words with the prefix "self", which gives them meaning: 1) the orientation of something towards oneself, proceeding from oneself or fulfilling for oneself; 2) turning to oneself, into oneself. Self-processes indicate the activity of the individual in various types of activity, and the development of the self is the ultimate goal of self-improvement of the individual.

Activation of personal potential in the process of a person's self-improvement and self-development leads to the emergence of autopsychological competence, which is associated with the processes of self-knowledge, self-esteem, self-control and selfregulation of behavior, state. This competence reflects the readiness and ability of a person to purposefully work to change personality traits and behavioral characteristics. It contributes to the formation of effective strategies for career and life development, optimal models of self-organization of life and professional activity.

Self-creation is one of the many self-processes that contribute to a person's achievement of perfection. Let us analyze the phenomenon of self-creation in the context of various scientific opinions and establish its connection with other selfprocesses that have a significant impact on the development and improvement of the teacher's professional image.

Ukrainian psychologist M. Boryshevsky interprets the process of self-creation as "an internal, active principle, a kind of entelechy of personality development" ability that provides the possibility of continuous changes in the structure of the personality as a dynamic, self-regulating and open system".

According to the apt remark of the scientist, self-creation is engaged by the one who does not consider himself perfect, but strives for this, knowing that this process is endless, but gracious, since it creates a feeling of progress, achieving something new [4, p. 43-44].

L. Serdyuk considers the self-creation of personality as a self-determined, complexly organized phenomenon, conditioned and mediated by a complex of interrelated personality parameters, in particular, the value of self-development, the integrity of the perception of the life path, self-acceptance, self-confidence, readiness for self-change, etc. Basic vectors of the process model self-creation of the personality is the need for self-development (self-realization), self-acceptance and life perspective of the personality [12, p. 14].

Self-creation is manifested in the active and meaningful actions of a person, aimed at himself, to develop qualities that correspond to a given situation, ideals, life goals of a person, from this it follows that a person himself is the author of his own changes.

Self-creation as self-change is not a change of oneself in relation to the external objective world, but an internal transformation leading to self-affirmation and selfdevelopment of the individual.

In the process of self-creation as self-movement, a person changes not only 
himself, but also the external environment, the conditions of his life. Self-creation, selfformation of a person occurs in spite of external and internal opposition. Self-alignment of the individual takes place according to his own project, personally chosen by means and materials, on a certain moral basis.

Thus, in the psychological and pedagogical literature, the category of "selfcreation" is understood as the transformative activity of a person, coupled with selfawareness of oneself as a subject of professional activity, self-realization of natural and creative potentials, provided by means of self-organization, self-education, personal and professional self-improvement, conscious self-reflection, self-regulation, selfcontrol and self-government in the process of educational creative activities aimed at achieving an effective result.

Representatives of psychological science believe that the process of self-creation of a person is realized through the interaction of various self-processes. Let us consider those that, in our opinion, have a systemic influence on self-creation and ensure the integrity and effectiveness of the result obtained - these are self-organization, selfregulation, self-presentation, self-image, self-management, self-marketing.

In this regard, we believe that self-organization and self-regulation are aimed at streamlining volitional and psychological aspects of activity; self-presentation and selfimaging contribute to the creation of a favorable impression of the individual in society and at the same time act as a means of his personal and professional development; selfmanagement and self-marketing create the prerequisites for the career growth of an individual and provide favorable conditions for his profitable promotion in the labor market in the context of educational competition. As a result of the impact of these processes, professionally significant personality traits are formed: purposefulness, organization, responsibility, efficiency, etc.

Self-organization. Self-organization - clear planning of your life, your affairs for the day, week, month, year, and for the future. It is rational use of your time and energy. Such an organization of their activities, which gives not only concrete results, but also brings satisfaction from the process itself, mobilization of oneself to achieve the goal and, if necessary, the ability to relax, relieve muscle and emotional tension, using the techniques of auto-training, relaxation [1, p. 120].

The modern reference literature contains various formulations of this concept.

Self-organization is the activity and ability of a person associated with the ability to organize oneself, which are manifested in purposefulness, activity, validity of motivation, planning their activities, independence, quick decision-making and responsibility for them, criticality of assessing the results of their actions, a sense of duty "[14, p. ... 329].

The analysis of scientific works on the problem of self-organization of the individual made it possible to identify its various types, and this, in our opinion, confirms the multifaceted and interdisciplinary nature of this concept.

In particular, professional self-organization is considered as an important personal characteristic, as a systemic quality that ensures the effectiveness of activity, regardless of its content and specifics, and manifests itself in the motives of behavior, and is also realized in orderly activities. 
Psychologists assign professional self-organization the role of a special psychological phenomenon, the essence of which is the desire of a specialist for constant professional self-development, self-improvement and self-preservation in a situation of variability of the professional space, is a mechanism for the formation and development of a professional self-concept, as well as a means of implementing the self-concept in professional activity and turns out to be in the totality of the processes of self-preparation (self-knowledge and self-development) and self-realization (selfexpression and self-affirmation).

Scientists pay attention to the connection between self-organization and volitional qualities of the individual. In their opinion, the personality as a self-governing system is characterized by: self-organization (the ability to organize oneself and one's activities in order to realize one's existing potential as fully as possible), self-discipline (the ability to control one's behavior, subordinate one's activity to established goals), selfmotivation (motivation of oneself to activities, the desire to reveal their potential), selfcontrol (assessment of their own actions, adjusting their own behavior) [3, p. 187].

The authors who reveal the issues of self-organization often touch upon the issues of self-regulation of activity, since they see a lot in common in the content of these two self-processes.

Self-regulation. A. Bandura reveals the essence of the concept "self-regulation" in the context of the social-cognitive theory of personality. According to the authoritative scientist, self-regulation is a cognitive characteristic of a person, which provides the ability to assess and correct their own behavior based on internal standards [2].

Self-regulation is the process of managing one's own psychological and physiological state, as well as actions; the ability to manage their own mental states and behavior in order to optimally act in difficult situations; the ability to manage environmental events and your own behavior; expedient self-organization of behavior, an objective assessment of the actually achieved results.

The works by Ukrainian scientists are devoted to the study of the issues of selfregulation of subjects of pedagogical activity (V. Bondar, I. Bekh, S. Goncharenko, M. Grineva, I. Zyazyun, N. Evtukh, S. Maksimenko, N. Nichkalo, E. Pekhoty, O. Pometun , L. Romanishin, S. Sysoeva and others).

M. Grineva considers self-regulation as the ability of a person to see the ultimate goal of activity, independently find the best ways to achieve it and achieve implementation, as the ability of an individual to create a program of activity and, on this basis, to manage his actions. According to the scientist, the result of self-regulation is the education of purposefulness, organization, the ability to control oneself, while self-regulation is a component of general giftedness, the fundamental principle of "general abilities". [5].

O. Konopkin defined the concept of "self-regulation of pedagogical activity", which is actively used in psychological and pedagogical research. By self-regulation of a teacher, a scientist understands the creation of desired or necessary states that would ensure the effectiveness of pedagogical actions, a psychologically comfortable atmosphere during pedagogical interaction, the development of reflection, endurance, 
the ability for introspection, self-control, and self-organization [11].

Scientists have come to the conclusion that self-regulation in educational and pedagogical activities is associated with the need to overcome the stresses caused by these types of activities and is aimed at optimizing the emotional sphere of the mental states of students and teachers.

For this purpose, it is necessary to use techniques to relieve emotional tension, normalize mental and physical conditions, and restore personality resources. Also, methods are used to improve the behavioral skills of communication, self-confidence, the development of positive thinking.

Self-presentation. The term "self-presentation" was first used in 1959 by Erving Goffman, the author of the concept of "social drama". His work is widely known "Presentation of Self in Everyday Life" [E. Goffman, 1959], which still remains fundamental for the analysis of the phenomenon of self-presentation.

Self-presentation (English - self-presentation, Amer. - own-presentation) is interpreted as "showing oneself to other people." According to the English version, it is the management of the impression of oneself using numerous behavioral strategies. In the American tradition, it is a form of social behavior, demonstratively accentuated by the subject in the process of interpersonal communication. For quite a long time, the concepts of "self-presentation", "self-disclosure", "self-presentation" were more familiar to our country.

Some scholars consider self-presentation in the context of social perception (as a process of purposefully drawing attention to the peculiarities of a person's appearance and behavior); in the context of communicative behavior (as an effective means of creating a certain impression among others and organizing their own behavior).

Foreign and domestic specialists have developed strategies and techniques for effective self-presentation that can be used by representatives of any profession.

The name of the American psychologist R. Cialdini is associated with extraordinary techniques for managing personal impressions:

1. The technique of enjoying reflected glory ("basking in reflected glory") - using someone else's success to present oneself.

2. Technique of harm ("sabotage") (blasting) - deliberate exaggeration of shortcomings (situation, object, another person, etc.) to improve their status, their growth in the eyes of others, which allows you to control the impression of others.

The listed strategies and techniques are based on the fact that successful selfpresentation is the presentation of a selection of features introduced into the behavior of an individual through the prism of his social experience in order to attract the attention of the audience with the subsequent management of the impression of himself.

Summarizing the opinions of different scientists, one can define the essence of self-presentation as an intentional human behavior based on internal motives or on the requirements of the situation, aimed at creating a concrete (positive) impression of oneself among others.

Self-imaging. In order to comprehensively study the phenomenon of selfcreation, M. Borishevsky uses the concepts of "inner image" and "social image" in his 
works. By social image, a scientist means image. According to his observations, “... chronologically, the first thing for a person who takes the path of self-improvement is a change in the social image - image. Expanding social ties and increasing their diversity by including the individual in new social situations and activities create new internal opportunities for self-creation "[12, p. 28].

The word "image" (English - image, Latin - imago) means "statue", "idol", "assimilation", "metaphor", "icon". The most commonly used meaning in speech is "image". Hence, the image is a certain synthetic image that is created in the minds of people in relation to a specific person, organization or other social object; includes a significant amount of emotionally colored information about the object of perception and encourages certain social behavior.

Distinguish between personal (individual, personal) image and professional image (image of a specialist, professional). In social and humanitarian studies, the concepts of "self-image", "self-promotion" and "personal brand" are also used.

As A. Klipikova notes, if the image that a person provides to the world around him is formed spontaneously, unconsciously and reflects the level of his self-esteem, we are talking about self-image. The impression of a person, based on spontaneous self-image, can range from strongly negative to excellent. If the means of forming the image are used consciously, purposefully and thoughtfully, they talk about a personal brand. Formation of a personal brand requires focusing on the needs of the audience and the situation, which means that a person strives only for positive manifestations of his own "I". A comparative study of the concepts of "self-image" and "selfpresentation" allowed the scientist to draw the following conclusion: self-presentation is built taking into account external requirements, and the image of a person is determined by his inner world [9, p. 96].

In our opinion, both concepts - "self-imaging" and "self-presentation" are associated with the activity of creating and presenting the audience with their own image. In modern society, the image is an indicator that helps people interact. This process involves, on the one hand, the person who creates his own image, on the other, the one who perceives this image. Of course, the process is mutual, and this allows you to create an impression of others, to understand by external manifestations - by dress, speech, non-verbal signals, manners - their life positions, values, to determine possible models of their behavior.

The process of creating an image is called imaging. The imaging procedure uses a complex of theoretical knowledge from the field of psychology, psychotherapy, ethics, aesthetics, orthobiotics, conflictology, medicine and, at the same time, it relies on practice-oriented areas: rhetoric, plastic, gesture, etiquette, cosmetology, fashion, fashion design and accessories, hairdressing, body and face building, etc.

Self-imaging is the process of creating your own image with specified properties, as well as transforming an existing image in order to achieve the set goals.

Creating your own image is a long and complex process, the success of which depends on the conditions and technologies for its formation. Determination and analysis of the mechanisms for building an image, knowledge of its essence and characteristics provide opportunities for the successful reproduction of social 
stereotypes in one's own image and the effective implementation of certain behavioral models.

Self-management. The concept of "self-management" was introduced into scientific circulation by the director of the German Institute for the rational use of time, Lothar Seivert, who interpreted it exclusively as "consistent and purposeful use of proven working methods in everyday practice in order to optimally and meaningfully use your time."

Self-management is a consistent and purposeful use of effective methods, techniques and technologies for self-realization and self-development by a person of his creative potential. The goal of self-management is to make the most of your capabilities, consciously manage the course of your life, taking into account external circumstances, and timely solve problems in your personal life and at work. The main functions of self-management include: goal setting, planning, decision-making, implementation of plans, control, communication and information.

Important aspects of personality self-management are the rational use of time, avoidance of stressful situations, correction of behavior in stressful situations, the ability to interact with team members, self-presentation, gaining approval of one's actions from others, and effective use of one's own capabilities. A feature of selfmanagement is that a person is a subject and an object of management at the same time.

There are several directions for the development of self-management:

1) time management - the technology of rational distribution and increasing the efficiency of time use;

2) stress management - a set of measures to prevent the occurrence of stressful situations and rehabilitation of the individual after their occurrence, as well as to strengthen its stress resistance;

3) team management (team management) - a modern approach to team building, management of changes and conflicts in the team, increasing the efficiency of teamwork;

4) impression management - the technology of forming a positive impression of yourself; a set of methods and principles for the formation of an attractive image;

5) resource management - the ability of a person to demonstrate competence in self-development [15, p. 128].

We support the opinion of scientists that self-management is especially important for managers who must not only manage their lives, ensure their growth, but also rationally organize the work of their immediate subordinates, create a favorable environment for their development. Indeed, not only the effectiveness of the team headed by them depends on the effectiveness of their activities, but also the activities of the organization as a whole [3, p. 187].

Thus, possession of self-management skills provides an individual with the opportunity to "consciously create his own life." Self-management ability is a versatile tool for self-creation.

Self-marketing. Self-marketing (from the English self and marketing) is an interconnected set of activities that includes an objective assessment of their knowledge and skills, business qualities and psychological characteristics in a certain 
environment, in relation to a specific workplace, as well as a set of methods and means for self-improvement, to improve the quality and level of their knowledge and skills, to develop their personal business qualities and psychological characteristics in the necessary direction.

The goal of self-marketing is to know and effectively realize oneself. Determine your sides, interests, inclinations, opportunities, qualities. To highlight to the employer exactly what will arouse his interest and desire to take on a job. In the modern world, there is a constant competition for the best job. The job of any job seeker is to be a winner.

D. Dmitrieva understands self-marketing as a complex of interrelated actions, which includes an objective assessment of one's knowledge, skills, abilities, personal and business qualities in relation to a specific workplace, as well as a set of methods and means for self-improvement and self-presentation.

The main goal of self-marketing is to promote itself in the labor market and profitably sell its labor. According to the researcher, self-marketing is one of the means of successful employment and career growth of a young specialist [9]. Recently, programs called "self-branding" (self-promotion, creation and "promotion" of oneself as a professional) have gained popularity in the world community. Such programs help graduates of higher educational institutions to decide on their first job, contribute to the career advancement of a young specialist - it is advisable to draw up and update them every five years. The program should contain specific actions, measures to improve professionalism and acquire skills, improve qualifications, class and create a name in the professional community, as well as methods, deadlines and budget for their implementation [13, p. 149-150].

Since self-promotion involves the open presentation of evidence of their competence and qualifications in order to be appreciated and, thanks to this, to receive advantages in the selection of candidates for appointment to a position, receiving encouragement, etc., a young specialist needs to master the means and techniques for implementing the program self-promotion in the profession.

Discussion. The study of published scientific works on the problem of personal and professional self-creation showed that their authors (M. Borishevsky, A. Ostapchuk, L. Serdyuk, T. Tsymbal, etc.) consider this phenomenon from the standpoint of psychological science. We set ourselves the goal of studying the phenomenon of self-creation and the accompanying self-processes in order to further apply this knowledge for the formation and development of personal qualities of future specialists in the field of education management. In our opinion, these should be qualities that characterize a future manager as a self-sufficient and competitive person with professional skills and personal characteristics necessary for a modern specialist in any industry in a market economy.

For example, the knowledge and skills of self-management and self-marketing are necessary for applicants for higher education already during their studies at the university. It was also noticed that their role significantly increases at the stage of employment and career building, since new opportunities open up for the development of business qualities and professional abilities of the future manager, improving his 
skills of self-management and management of other people and production processes in general. The elements of self-presentation and self-imaging are important for every young person who wants to show their external and internal qualities in such a way as to gain credibility with the management and subordinates, to be confident in themselves and their actions in order to meet the tough conditions of competition in the educational services market.

In our opinion, an urgent need for the higher education system is the introduction into the educational process of the university of a cycle of special educational disciplines aimed at developing and improving the personality of the future professional: "Theory and practice of self-management", "Competitionology", "Imageology", etc.

Conclusion. In modern conditions of reforming the education system in Ukraine, the relevance of educational management is increasing and the need for high-quality training of qualified specialists for the field of education management is growing. A promising direction for improving the quality of professional training of future education managers is to solve the problem of professional self-creation of specialists of this profile in the conditions of university education. The content-procedural aspect of the professional self-creation of the future education manager is a set of interrelated self-processes: self-organization, self-regulation, self-presentation, self-image, selfmanagement, self-marketing, which ensure the effectiveness of professional creation of a specialist in the sphere of management. Under the influence of the indicated selfprocesses, favorable conditions are created for the personal and professional development of the future manager in the field of education, the prerequisites for career growth and profitable promotion of a specialist in the labor market in conditions of educational competition arise.

Author contributions. The authors contributed equally.

Disclosure statement. The authors do not have any conflict of interest. References:

1. Andreev V. Y. Konkurentolohyia. Ucheb. kurs dlia tvorcheskoho samorazvytyia konkurentosposobnosty. Kazan: Tsentr ynnovatsyonnыkh tekhnolohyi, 2004. $468 \mathrm{~s}$.

2. Bandura A. Teoryia sotsyalnoho nauchenyia. SPb.: Evrazyia, 2000. $320 \mathrm{~s}$.

3. Buniak N. M. Samomenedzhment yak mystetstvo samorozvytku osobystosti. Hlobalni ta natsionalni problemy ekonomiky. 2017, № 8. URL: http://global-national.in.ua/archive/18-2017/36.pdf.

4. Boryshevskyi M. Kontseptualni zasady problemy samotvorennia osobystosti. Psykholohiia osobystosti. 2013. №1. S. 39-47.

5. Hrynova M. V. Samorehuliatsiia [Tekst]: Monohrafiia. Poltava: ASMI, 2008. 268 s.

6. Huba A. V. Teoretyko-metodychni zasady formuvannia upravlinskoi kultury vchytelia - maibutnoho menedzhera osvity: avtoref. dys. ... dokt. ped. nauk: spets.13.00.04 /Luhanskyi nats. un-t im. T. Shevchenka. Luhansk, 2010. 44 s.

7. Dmytryeva D. D. Samomarketynh kak sredstvo uspeshnoho trudoustroistva molodoho spetsyalysta. Ynnov: эlektronnыi nauchnыi zhurnal, 2018. №6 (39). URL: http://www.innov.ru/science/economy/samomarketing-kaksredstvo-uspeshno/

8. Zhyhir V. I. Providni funktsii menedzhera osvity yak osnova formuvannia yoho profesiinoi kompetentnosti. Molod i rynok. 2011. №2 (73). S. 27-33.

9. Klypykova A. A. Samoymydzh y samoprezentatsyia: k voprosu sootnoshenyia poniatyi. Эkonomycheskye y sotsyalno-humanytarnыe yssledovanyia. 2017. № 3 (15). S. 92-96.

10. Kolominskyi N. L. Psykholohiia menedzhmentu v osviti (sotsialno-psykholohichnyi aspekt) [Tekst] : monohrafiia. K. : MAUP, 2000. $286 \mathrm{~s}$.

11. Konopkyn O. A. Psykholohycheskye mekhanyzmы rehuliatsyy deiatelnosty: [monohrafyia]. Yzd. 2-e, yspr. y dop. Moskva: Lenand, 2011. 320 s. 
12. Samotvorennia u rozvytku osobystosti: naukovo-metodychnyi posibnyk / L. Z. Serdiuk, T. M. Yablonska, O. I. Penkova, N. D. Volodarska [ta in.]; za red. L. Z. Serdiuk. K.: Pedahohichna dumka, 2015. 93 s.

13. Semenova L. M. Samomarketynh y samobrendynh spetsyalysta v sfere kommunykatsyi kak uslovye povыshenyia konkurentosposobnosty na rыnke truda. Vestnyk YuUrHU. Seryia «Эkonomyka y menedzhment». 2014. T. 8. № 4. S. 145-151.

14. Slovar praktycheskoho psykholoha [Tekst] / Sost. S. Yu. Holovyn. Mynsk: Kharvest, 1998. $800 \mathrm{s.}$

15. Shtepa O. S. Samomenedzhment: definitsiia ta diahnostyka. Nauka i osvita. Naukovo-praktychnyi zhurnal Pivdennoukrainskoho universytetu APN Ukrainy. Spetsvypusk «Psykholohiia osobystosti: teoriia, dosvid, praktyka». 2009. № 8. S. 128-130.

Received: November 02, 2021 Approved: December 24, 2021 